\title{
Regulation of leptin gene expression by insulin and growth hormone in mouse adipocytes
}

\author{
Kyung No Lee', In Cheol Jeong', Song Jae \\ Lee ${ }^{1}$, Sang Hwan $\mathrm{Oh}^{2}$ and Moo Youn $\mathrm{Cho}^{1,3}$ \\ ${ }^{1}$ Department of Biochemistry, College of Medicine, \\ Koshin University, Busan 602-702, Korea \\ ${ }^{2}$ Department of Biochemistry \& Molecular Biology, \\ College of Medicine, Yonsei University, Seoul 120-752, Korea \\ ${ }^{3}$ Corresponding author: Tel, +82-51-990-6416; \\ Fax, +82-51-241-5458; E-mail, mycsed@ns.kosinmed.or.kr
}

Accepted 29 November 2001

Abbreviations: DEPC, diethyl pyrocarbonate; BW, body weight; SDS, sodium dodecyl sulfate; ECL, enhanced chemiluminescence; IgG, immunoglobulin G; ELISA, enzyme-linked immunosorbent assay; s.c, subcutaneous

\begin{abstract}
The role of leptin in the control of obesity, insulin resistance and type II diabetes has been reported, however, the regulatory mechanism of leptin in animals affected by hormones is not clearly understood. In this study, the effects of insulin, epinephrine, growth hormone or dexamethasone on the expression of leptin was examined in mouse primary adipocytes. The leptin expression was also studied in the adipose tissue of the mouse treated with insulin or growth hormone (0.3 or 0.6 units/animal). Insulin (100 nM) or dexamethasone (100 nM) stimulated leptin mRNA transcription while epinephrine (100 $\mathrm{nM})$ alleviated its transcription in mouse primary adipocytes. The level of leptin protein in cultured media of adipocytes treated with insulin or dexamethasone was higher than that of the control group but growth hormone or epinephrine treatment had no effect on them. Insulin administration (0.6 units/mouse) enhanced leptin mRNA as well as leptin protein in mouse adipose tissue but growth hormone administration ( 0.3 or 0.6 units/mouse) had no effect on them. Leptin protein level in sera of mice injected with insulin or growth hormone was not significantly different from that of control group. These results indicate that both insulin and dexamethasone stimulate leptin gene expression and secretion of its product, whereas, growth hormone has no effect on the expression of leptin gene in mouse adipocytes.
\end{abstract}

Keywords: Leptin, Insulin, Growth hormone, Expression

\section{Introduction}

Leptin, a cytokine secreted mainly from adipocytes is $o b$ gene product of which primary function is thought to regulate energy balance (Zhang et al., 1994). It is well known that leptin has physiological effects such as the reduction of food intake (Pelleymounter et al., 1995) and increase of metabolic rate by signal transduction between brain and adipose tissue (Campfield et al., 1995). Recently, the potential role of leptin in cell proliferation and angiogenesis has also been suggested (Park et al., 2001). The discovery of anti-obesity action of leptin contributed to the understanding of clinical-pathology related to the change of body weight and body composition. It has been documented that obesity is associated with insulin resistance and non-insulin dependent dialetes mellitus (Saladin et al., 1995). But the role of leptin in the control of insulin resistance and diabetes melitus is unknown.

The stimulatory effect of insulin, cAMP and glucocorticoid on the gene expression and secretion of leptin has also been reported (Slieker et al., 1996). On the other hand, leptin inhibited insulin secretion either by the activation of $\mathrm{K}_{\text {ATP }}$ chanel (Felber et al., 1993) or by the feedback inhibition of insulin gene expression (Docherty et al., 1991), suggesting that insulin and steroid hormones are involved in the regulation of leptin status in animals.

Reduced secretion and insensitivity of growth hormone are seen in obese patients (Rodbell, 1964; Bercu et al., 1998), and the secretion of growth hormone is influenced by metabolic regulators such as glucose, free fatty acids, amino acids, steroid hormones and thyroid hormones (Stewart et al., 1989; Lanzi et al., 1997; AlbaRoth et al., 1998). But, the functional relationship between leptin and growth hormone has not yet been determined.

These results implicate that leptin involves in signal transduction system related to body fat accumulation and various hormones related to body fat composition might influence its function. The metabolic state of animal affected by hormones and various metabolic mediators is closely linked to obesity and expression of ob gene. In this study, obesity of animals under the influence of hormones regulating the metabolic state of animal was evaluated in vitro by measuring the expression of leptin in the adipocytes of mouse treated with insulin, epinephrine, growth hormone or dexamethasone. In addi- 
tion, effects of insulin and growth hormone on the leptin gene expression in mouse adipose tissue were investigated.

\section{Materials and Methods}

\section{Animals and Cells}

Fifteen male ICR mice ( $50 \mathrm{~g} \mathrm{BW}$ ) were fed with commercial rat chow ad libitum and tap water was supplied to consume freely. Animals were divided into five groups ( 3 mice per group) and 0.3 or 0.6 units of insulin or growth hormone (dissolved in $0.5 \mathrm{ml}$ of physiological saline) per mouse were injected s.c. Control group received the same amount of physiological saline solution. Blood was drawn from each mouse at $24 \mathrm{~h}$ after the injection of hormone and serum was separated from blood by centrifugation at $1,000 \mathrm{~g}$ for $15 \mathrm{~min}$ at room temperature and saved for the analysis. All mice were sacrificed after drawing blood. Adipose tissue in epididymal fat was removed and washed twice with saline solution and saved for the analysis of leptin expression.

For the preparation of mouse adipocytes, adipose tissue was sliced into $3 \mathrm{~mm}$ thickness, added with $5 \mathrm{ml}$ of bicarbonate buffer $\left(25 \mathrm{mM} \mathrm{NaHCO}_{3}, 12 \mathrm{mM} \mathrm{KH}_{2} \mathrm{PO}_{4}\right.$, $1.2 \mathrm{mM} \mathrm{MgSO}_{4}, 4.8 \mathrm{mM} \mathrm{KCl}, 120 \mathrm{mM} \mathrm{NaCl}, 1.4 \mathrm{mM}$ $\mathrm{CaCl}_{2}, 5 \mathrm{mM}$ glucose, $2.5 \% \mathrm{BSA}, 50$ units penicilline, 10 ng streptomycin, $\mathrm{pH} 7.4$ ) containing $10 \mathrm{mg}$ of bacterial collagenase and digested for $1 \mathrm{~h}$ at $37^{\circ} \mathrm{C}$ with a mild rocking. Adipocytes released from the tissue were harvested by centrifugation (400 $\mathrm{g}, 15 \mathrm{~min}$ ). Cells in upper phase in centrifuge tube were collected, washed three times with the fresh bicarbonate buffer and resuspended in Dulbecco's modified Eagles medium (DMEM) containing $10 \%$ fetal calf serum. For the treatment of hormones adipocytes were divided into five groups; insulin, epinephrine, growth hormone, dexamethasone and control groups. Cells in culture plate $\left(7.5 \times 10^{5}\right.$ cells $\left./ \mathrm{ml}\right)$ for each group were treated by addition of $100 \mathrm{nmol}$ of each corresponding hormone to DMEM $(4 \mathrm{ml} /$ well) and incubated for the experimental period indicated. Cells and media in each plate were harvasted at 0, 6, 12 and 24 $\mathrm{h}$ after the hormone treatment and saved for the analysis of leptin. Preparation and culture of adipocytes were performed in aseptic conditions described by Rodbell (1964).

\section{Quantitative RT-PCR}

Total RNA in mouse adipose tissue was isolated using Tri agent (Amersham Life Science Ltd., Buckinghamshire, England). The detailed methods are described in the manual supplied by the company. Reverse transcription of leptin mRNA was carried out by incubating a mixture (final $20 \mu \mathrm{l}$ ) containing $1 \mu \mathrm{g}$ of total RNA dissolved in 8 $\mu \mathrm{l}$ of DEPC-treated water with $2 \mu \mathrm{l}$ of $5 \times$ reaction buffer
(250 mM Tris-Cl, pH 8.3, 25 mM KCl, 50 mM DTT, 50 $\mathrm{mM} \mathrm{MgCl} 2$ ) at $65^{\circ} \mathrm{C}$ for $10 \mathrm{~min}$, followed by incubation for $1 \mathrm{~h}$ at $37^{\circ} \mathrm{C}$ after addition of $1 \mu \mathrm{l}$ of antisense primer for leptin cDNA (100 pmol), $1 \mu \mathrm{l}$ of dNTP $(10 \mathrm{mM}), 1 \mu \mathrm{l}$ of RNase inhibitor (20 units), and $1 \mu$ of reverse transcriptase (10 units). After the incubation, the reaction mixture was taken into boiling water bath and incubated for $5 \mathrm{~min}$ to inactivate the enzyme. Quantitative PCR was performed by the method of Saiki et al. (1988) using sense and antisense primers corresponding to leptin cDNA sequence together with leptin cDNA as template.

\section{Northern blot hybridization}

Total RNAs isolated from adipocytes or adipose tissue of mice administered with various hormones were subjected to formaldehyde agarose gel electrophoresis according to the previously described method (Kim et al., 2000) and RNAs separated on the gel were electrophoretically transfered onto nitrocellulose membrane. Leptin mRNA was hybridized with ${ }^{32} \mathrm{P}$-labeled leptin cDNA and detected by autoradiography.

\section{Western blot immunodetection}

Proteins from adipocytes and adipose tissue of mice treated with various hormones were extracted by differential centrifugation after homogenizing cells or tissue with tissue homogenizer, and soluble fractions were subjected to SDS-polyacrylamide gel electrophoresis according to the method of Laemmli (1970) and proteins separated on the gel were electrophoretically transfered onto nitrocellulose membrane. Leptin protein was identified by ECL-associated immunochemical analysis using anti-leptin rabbit antibody as a primary antibody $(1: 2,000$ dilution) and horse radish peroxidase-conjugated antirabbit IgG antibody as a secondary antibody $(1: 1,000$ dilution). The content of leptin in sera of mice was measured by two-site ELISA according to the method of Johnston and Thorpe (1987). The antibodies used in ELISA were same as that used in Western blot immunodetection analysis. Total protein content was measured by Bradford method (1976).

\section{Results}

\section{Effect of hormones on the transcription of leptin mRNA in mouse adipocytes}

Adipocytes treated with insulin (100 nM) caused an increase of the leptin mRNA expression level, whereas the epinephrine $(100 \mathrm{nM})$ affected the cells by lowering leptin expression. Both growth hormone and dexamethasone also induced an elevation of leptin mRNA level in mouse adipocytes as shown in RT-PCR analysis (Figure 1). 

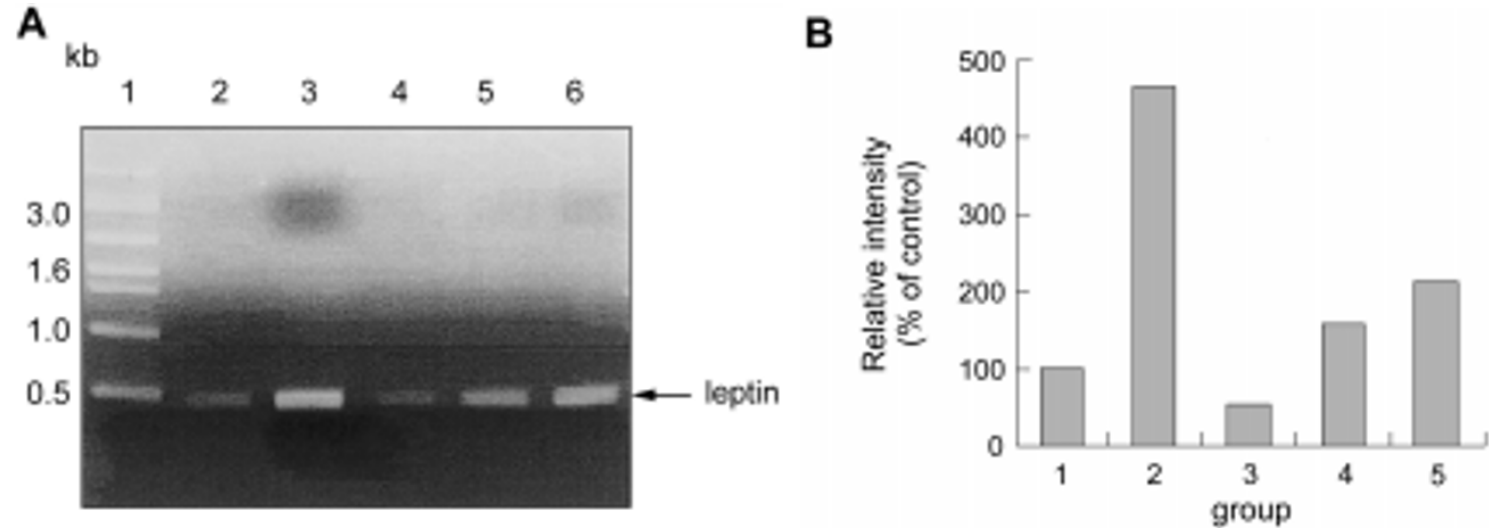

Figure 1. Effect of insulin, epinephrine, growth hormone and dexamethasone on the expression of leptin mRNA in mouse adipocytes. Mouse adipocytes were treated with each respective hormones $(100 \mathrm{nM})$ and cultured for $24 \mathrm{~h}$. Cells were harvested and total RNAs were prepared and used as templates for the detection of leptin mRNA by RT-PCR (A). Lane 1, DNA molecular size marker; lane 2, control; lane 3, insulin treated; lane 4, epinephrine treated; lane 5, growth hormone treated; lane 6, dexamethasone treated. Relative intensity of the amplified CDNA bands of leptin (B) was calculated from densitogram of the CDNA bands appreared in A panel and expressed as \% of the control. Group 1, control; group 2, insulin treated; group 3, epinephrine treated; group 4, growth hormone trearted; group 5, dexamethasone treated.

\section{Leptin protein level in the culture media of mouse adipocytes treated with various hormones}

Treatments with insulin $(100 \mathrm{nM})$ or dexamethasone (100 nM) of mouse primary adipocytes increased leptin protein level in the culturerd media of mouse adipocytes, indicating that both insulin and dexamethasone stimulated the expression of leptin gene and secretion of its product in adipocytes. However, treatments with neither growth hormone (100 nM) nor epinephrine (100 $\mathrm{nM}$ ) caused any significant change in leptin protein level in the cultured media of adipocytes as compared to that of the control group, indicating that both growth hormone and epinephrine had no effect on the expression of leptin gene and secretion of its product in adipocytes

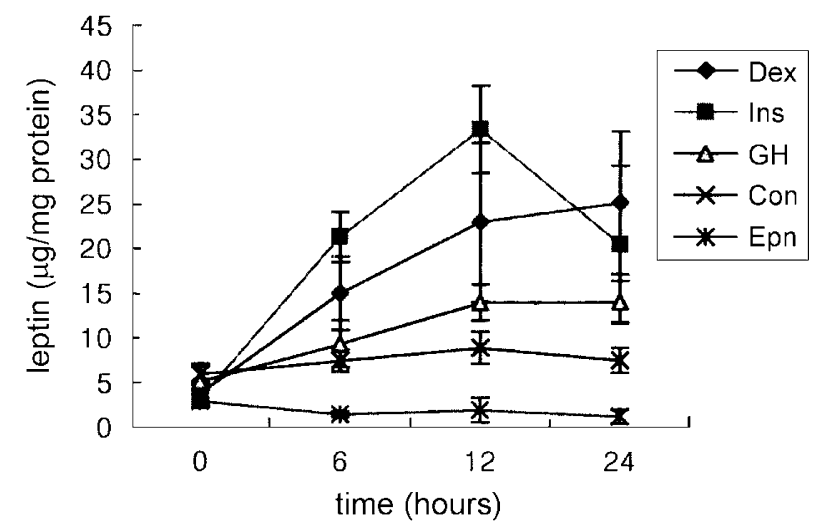

Figure 2. Expression and secretion of leptin from mouse adipocytes treated with $100 \mathrm{nM}$ of each insulin (Ins), epinephrine (Epn), growth hormone (GH) and dexamethasone (Dex). Control (Con) cells were treated with saline and cultured for $24 \mathrm{~h}$. A fraction of the culture media (1 ml) were taken at 0,6 , $12,24 \mathrm{~h}$ after the hormone treatment and leptin protein secreted into media of each time point was measured by ELISA method. Leptin content was calculated from standard curve constructed from purified recombinant leptin.
(Figure 2). Leptin protein level in adipocytes gradually increased for the first $12 \mathrm{~h}$ after the insulin treatment, then it decreased at $24 \mathrm{~h}$ after the hormone treatment, indicating that the effect of insulin added to the culture media of adipocytes may not persist longer than $12 \mathrm{~h}$.

\section{Effect of hormones on leptin protein level in mouse adipocytes}

Mouse primary adipocytes treated with insulin (100 nM) increased cellular leptin protein level, but the treatment with epinephrine rather decreased it. Administration of growth hormone or dexamethasone caused a slight increase in the leptin protein level in adipocytes without any significance (Figure 3). Leptin protein level in mouse

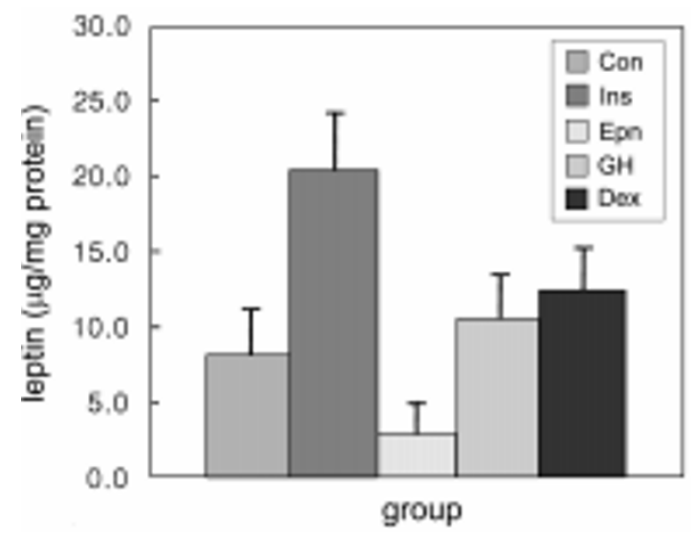

Figure 3. Detection of leptin protein in cultured mouse adipocytes treated with $100 \mathrm{nM}$ of insulin (Ins), epinephrine (Epn), growth hormone (GH) and dexamethasone (Dex) and cultured for $24 \mathrm{~h}$. Control cells (Con) received no hormone. Leptin protein in cell extract was subjected to ELISA. The amount of leptin was calculated from standard curve constructed by reference leptin protein (recombinant leptin). Bars indicate S.D. 
A

B
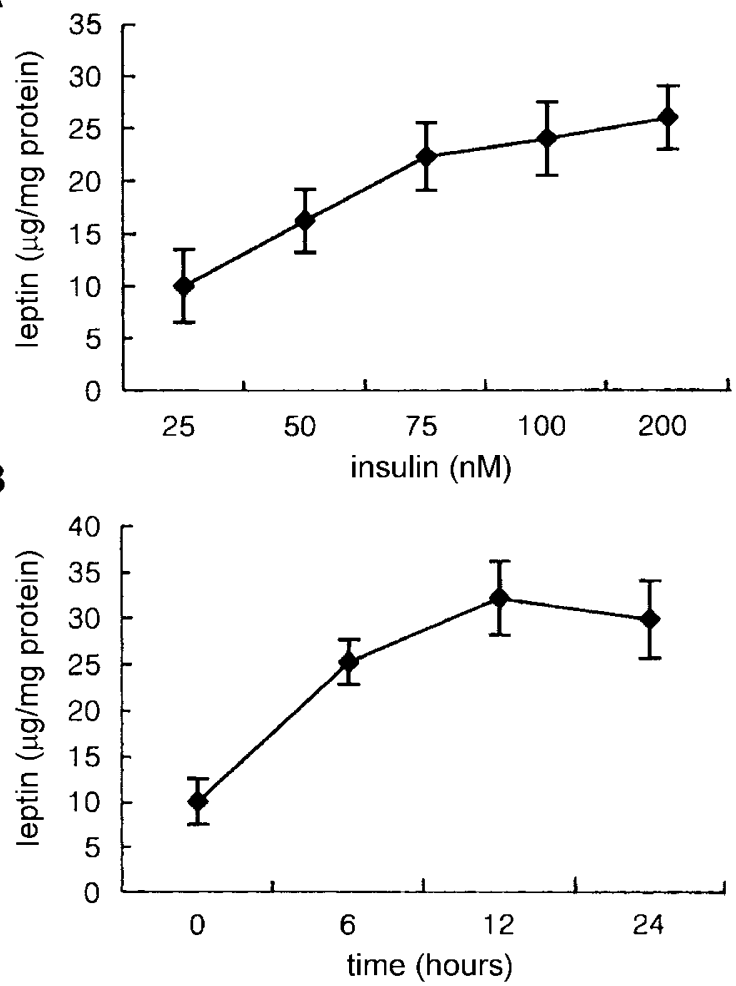

Figure 4. Effect of insulin on the leptin expression in cultured mouse adipocytes. Mouse adipocytes were treated with various amounts of insulin $(25,50,75100,200 \mathrm{nM})$ and cultured for $24 \mathrm{~h}$ (A). Adipocytes treated with insulin (100 nM) were cultured for $24 \mathrm{~h}$ and harvested at various time points indicated (B). Leptin in the cell extracts was measured by ELISA method.

adipocytes increased by insulin treatment in a dosedependent manner up to $75 \mathrm{nM}$ of insulin in the media but its further increment had no additional effect on leptin protein level in adipocytes (Figure 4A). Treatment of insulin (100 nM) to mouse adipocytes gradually increased leptin protein level in the cells for the first 12 $\mathrm{h}$ of culture, whereas it decreased slightly at $24 \mathrm{~h}$ of culture (Figure 4B).

\section{Effect of insulin and growth hormone on the expre- ssion of leptin in mouse adipose tissue}

The level of leptin mRNA in adipose tissue was increased by insulin ( 0.6 units/mouse) administration but the administration of growth hormone (0.3 or 6 units/ mouse) had no effect on mRNA transcription of leptin gene with (Figure 5). Western blot immuodetection for leptin protein expressed in adipose tissue of mice administered with insulin or growth hormone revealed that insulin increased leptin protein level in adipose tissue but growth hormone had no significant effect on it (Figure 6). Insulin administration to mice showed no change in leptin protein level in sera of mice but growth hormone administration rather decreased it with no

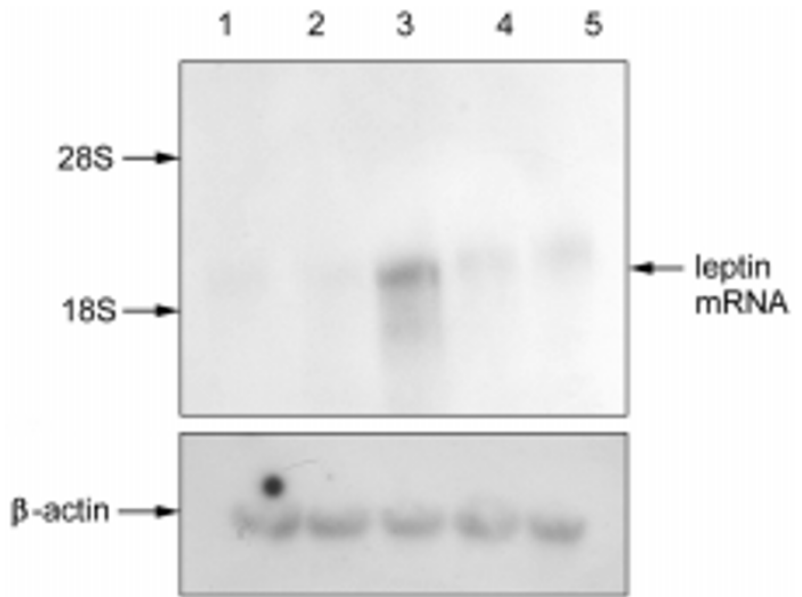

Figure 5. Effect of insulin and growth hormone on the expression of leptin mRNA in mouse adipose tissue. Mice were administered s. c. with insulin ( 0.3 or 0.6 units per mouse) or growth hormone ( 0.3 or 0.6 units per mouse) and sacrificed after $24 \mathrm{~h}$. Total RNA was prepared from adipose tissue (epididymal fat) and was subjected to Northern blot hybridization using a ${ }^{32} \mathrm{P}$-labelled leptin cDNA probe. Lane 1, control (mice injected with saline); lane 2, mice injected with insulin ( 0.3 units); lane 3, mice injected with insulin ( 0.6 units); lane 4. mice injected with growth hormone (0.3 units); lane 5, mice injected with growth hormone ( 0.6 units).

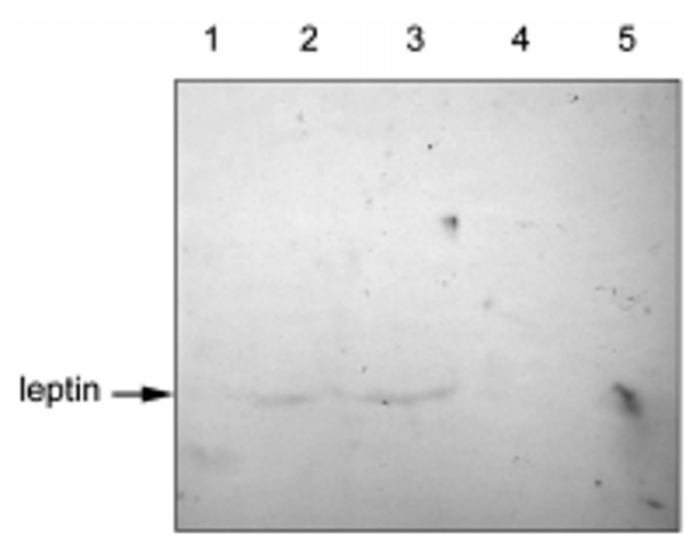

Figure 6. Western blot immunodetection of leptin protein in adipose tissue of mice administered with insulin or growth hormone. Lane 1, control mice injected with saline; lane 2, mice injected with insulin ( 0.3 units per mouse); lane 3 , mice injected with insulin ( 0.6 units per mouse); lane 4 , mice injected with growth hormone ( 0.3 units per mouse); lane 5 , mice injected with growth hormone (0.6 units per mouse).

statistical significance (Table 1).

\section{Discussion}

Leptin is synthesized in adipocytes and secreted into ciculateing blood to be transported to leptin receptors present at hypothalamus where it regulates food intake, thermogenesis and energy metabolism in adipose tissue (Bai et al., 1996). But the presence of leptin receptors in 
Table 1. Serum leptin level of mice administered with insulin or growth hormone

\begin{tabular}{lrrrr}
\hline Group & \multicolumn{3}{c}{ leptin $(\mathrm{ng} / \mathrm{ml})$} & \multicolumn{1}{c}{ means } \\
\hline Control & 10.8 & 12.4 & 9.9 & $11.0 \pm 1.3$ \\
Insulin (0.3U) & 10.2 & 13.1 & 16.3 & $13.2 \pm 3.0$ \\
Insulin (0.6U) & 13.0 & 14.6 & 11.5 & $13.0 \pm 1.6$ \\
Growth hormone (0.3U) & 8.9 & 9.7 & 9.6 & $9.3 \pm 0.6$ \\
Growth hormone (0.6U) & 9.2 & 10.3 & 9.4 & $9.6 \pm 0.7$
\end{tabular}

Leptin contents in sera were determined by ELISA assay. Each hormone was administered s.c. into mouse once a day for 3 days and serum sample was taken at $12 \mathrm{~h}$ after the last administration. No significant differences between groups are observed.

various peripheral tissues has been reported (Lee et al., 1996).

The increased leptin level in the media of adipocytes treated with insulin or dexamethasone in the present study reflects a consequence of an increased expression of leptin gene by these hormones in adipocytes. This result is consistent with the previously reported results by other investigators (Muller et al., 1997; Fain et al. 1998). From these results, it is assumed that insulin and dexamethasone of which functions are stimulation of lipolysis and glycogen synthesis in animals might exert their actions through a leptin-mediated event, and that the role of leptin can be potentiated by these hormones.

The stimulatory effect of insulin on the expression of leptin gene in adipocytes was paralleled up to $75 \mathrm{nM}$ of insulin but no further increase in leptin protein level was observed over $100 \mathrm{nM}$ insulin level in cells, indicating that $100 \mathrm{nM}$ of insulin was sufficient to attain the insulin effect on the expression of leptin gene in adipocytes without any adverse effects. Adipocytes treated with 200 $\mathrm{nM}$ of insulin maintained the stimulating effect on leptin gene expression without reduction of cellular viability in this study (data not shown).

Insulin level (100 nM) used in this study was much higher than the level $(3 \mathrm{nM})$ employed by Leroy et al. (1996), which was too low to attain a significant effect on leptin mRNA transcription in the present study. But the effect of low level $(3 \mathrm{nM})$ of insulin on leptin gene expression can not be ignored since the application of more sensitive probe for the detection of leptin will make it possible to differentiate the small amount of leptin in cells.

Mouse primary adipocytes prepared in the present study were viable for $28 \mathrm{~h}$ of experimental period and well accomodated themselves to the treatment of insulin, epinephrine, growth hormone and dexamethasone (100 $\mathrm{nM}$ each), which is the amount used by previous studies (Muller et al., 1997; Yasuda et al., 1997). Since the stimmulatory effect of insulin on leptin protein in adipocytes continued during the first $24 \mathrm{~h}$ and decreased slightly thereafter, the measurement of leptin in adipocytes and in the culture media was performed at $24 \mathrm{~h}$ after the treatment of various hormones.

It has been reported that leptin alleviated insulin effect in rat adipocytes (Muller et al., 1997), implicating that leptin is not only involved in glucose transfer and protein synthesis but also in feed back regulation of fat synthesis. Therefore, it is reasonable to assume that $o b$ gene expression in adipocytes may be regulated in response to insulin concentration in cells and that leptin may alleviate the hyperglycemia in diabetes melitus with high insulin resistance (Seufert et al., 1999).

In the present study, administration of insulin to mice increased leptin mRNA transcription in adipose tissue, while growth hormone caused a marginal increase. Consequently, the stimulatory effect of insulin on leptin mRNA transcription was obvious in vivo as well as in cell culture system, however growth hormone had little effect on leptin mRNA transcription in mouse adipose tissue.

Growth hormone level in animal tissues is influenced by insulin and obesity, but the regulatory mechanism of body fat decomposition by growth hormone is uncertain (Lanchi et al., 1997; Bercu et al., 1998). Since growth hormone showed little effect on the leptin status in adipocytes in the present study, it is assumed that the decreased endogenous growth hormone secretion in obese tissues observed by previous investigators (Bercu et al., 1998) is thought to be operated in some other mechanisms.

Insulin injection, three times a day for 3 days (0.6 units/mouse), increased leptin mRNA transcription in mouse adipose tissue, but growth hormone injection(0.6 units/mouse) could increase its transcription slightly. Similiar responses to these hormones in cultured adipocytes were also observed in this study. This result confirms the previous report that the expression of leptin mRNA in adipocytes increased transiently $4 \mathrm{~h}$ postinjection of insulin to fasted rat and its induction might be influenced by various hormones and factors related to the metabolism of sugars and lipids prior to or after the diet consumption (Saladin et al., 1995).

The facts that insulin administration increased leptin protein level in mouse adipose tissue in the present study support the idea of McDowgald et al. (1995) who insisted that insulin plays as a positive regulator for leptin biosynthesis.

Injection of insulin or growth hormone to mice showed no change in leptin level in sera of mice (Table 1), indicating that these hormones may not stimulate leptin secretion in vivo during the experimental period and that there might be some different mechanism for the regulaton of blood leptin level.

From these study, it is possible to conclude that insulin or dexamethasone stimulates leptin biosynthesis, which regulates the reduction of food intake and that growth hormone may not stimulate leptin biosynthesis in 
mouse adipocytes.

\section{References}

Alba-Roth J, Muller OA, Schopohl J, vonWerder K. Arginine stimulates growth hormone secretion by suppressing endogenous somatostatin secretion. J Clin Endocrinol Metabol 1998:67:1186-89

Bai Y, Zhang S, Kim SK, Lee JK, Kim KH. Obese gene expression alters the ability of $30 \mathrm{~A} 5$ preadipocytes to respond to lipogenic hormones. J Biol Chem 1996;271:13939-42

Bercu BB, Sculman DI, Root AW. Obesity decreases endogenous growth hormone secretion in children with normal growth velocities. Pediatric Res 1988;23:272A

Bradford MM. A rapid and sensitive method for the quantitation of microgram quantities of protein utilizing the principle of protein-dye binding. Anal Biochem 1976;72:24854

Campfield LA, Smith FJ, Guisez Y, Devos R, Burn P. A recombinant mouse $\mathrm{OB}$ protein: evidence for a peripheral signal linking adiposity and central neural networks. Science 1995;269:546-49

Docherty K, Clark AR, Scott V, Knight SW. Metabolic control of insulin gene expression and biosynthesis. Proc Nutr Soc 1991;50:553-58

Fain JN, Bahouth SW. Hormonal regulation of $18 \mathrm{~S}$ RNA, leptin mRNA, and leptin release in adipocytes from hypothyroid rats. Metabolism 1998;47:1455-61

Felber JP, Haesler E, Jequier E. Metabolic origin of insulin resistance in obesity with and without type 2(non-insulindependent) diabetes mellitus. Diabetologia 1993;36:1221-29

Johnston A, Thorpe R. Enzyme-linked immunosorbent assay (ELISA). Immunochemistry in practice (ed A. Johnston and $R$ Thorpe), 1987, pp257-59, Oxford, Blackwell Scientific Publication Co.

Kim HS, Jeong SY, Lee JH, Kim BE, Jeong SW, Kim IK. Induction of apoptosis in human leukemia cells by 3deazaadenosine is mediated by caspase-3-like activity. Exp Mol Med 2000;32:197-203

Laemmli UK. Cleavage of structural proteins during the assembly of the head of bacteriophage T4. Nature 1970; 227:680-85

Lanzi R, Manzoni MF, Andreotti AC, Maligetti ME, Bianchi E, Sereni LP. Evidence for an inhibitory effect of physiological levels of insulin on the growth hormone response to $\mathrm{GH}$ releasing hormone in healthy subjects. J Clin Endocrinol Metabol 1997;82:2239-43
Lee GH, Proenca R, Montez JM, Carroll KM, Darvishzadeh $\mathrm{JG}$, Lee JL, Friedman JM. Abnormal splicing of the leptin receptor in diabetic mice. Nature 1996;379:632-35

Leroy $\mathrm{P}$, Dessolin S, Villageois $\mathrm{P}$, Moon BC, Friedman JM, Ailhaud G, Dani C. Expression of $o b$ gene in adipose cells. J Biol Chem 1996;271:2365-68

McDougald OA, Hwang CS, Fan H, Lane MD. Regulated expression of the obese gene product (leptin) in white adipose tissue and 3T3-L1 adipocytes. Proc Natl Acad Sci USA 1995;92:9034-37

Muller G, Ertl J, Gerl M, Preibisch G. Leptin impairs metabolic actions of insulin in isolated rat adipocytes. J Biol Chem 1997; 272:10585-93

Park HY, Kwon HM, Lim HJ, Hong BK, Lee JY, Park BE, Jang YS, Cho SY, Kim HS. Potential role of leptin in angiogenesis: leptin induces endothelial cell proliferation and expression of matrix metalloproteinases in vivo and in vitro. Exp Mol Med 2001;33:95-102

Pelleymounter MA, Cullen MJ, Baker MB, Hecht R, Winters D, Boone T, Collins F. Effects of obese gene product on body weight regulation in ob/ob mice. Science 1995;269:540-43

Rodbell M. Metabolism of isolated fat cells. J Biol Chem 1964; 239:375-80

Saiki RK, Gelfand DH, Stoffel S, Scharf SV, Higuchi R, Horn GT, Mullis K, Erlich HA. Primer directed enzymatic amplification of DNA with a thermostable DNA polymerase. Science 1988;289:487-91

Saladin R, De Vos P, Guerre-Millo M. Transient increase in obese gene expression after food intake or insulin administration. Nature 1995;377:527-29

Seufert J, Kieffer TJ, Habener JF. Leptin inhibits insulin gene transcription and reverses hyperinsulinemia in leptin-deficient ob/ob mice. Proc Natl Acad Sci USA 1999;96:674-79

Slieker LJ, Sloop KW, Surface PL et al. Regulation of expression of $o b$ mRNA and protein by glucocorticoids and cAMP. J Biol Chem 1996;271:5301-4

Stewart PM, Smith S, Seth J, Stewart SE, Cole D, Edward CR. Normal growth hormone response to the $75 \mathrm{~g}$ oral glucose tolerance test measured by immunoradiometric assay. Ann Clin Biochem 1989;26:205-8

Yasuda G, Umemura S, Jeffries WB. Effect of epinephrine on cAMP accumulation in cultured rat inner medullary duct cells. Am J Physiol 1997;272:F192-97

Zhang Y, Proenca R, Marffei M, Barone M, Leopold L, Friedman JM. Positional cloning of the mouse obese gene and its human homologue. Nature 1994;372:425-32 